\title{
FAULT, ACCIDENTS AND THE WONDERFUL WORLD OF BLUM AND KALVEN
}

\author{
GUIDO CALABRESI $\dagger$
}

ThIs year Professors Walter Blum and Harry Kalven of the University of Chicago Law School published in book form the Shulman lectures they had previously given at Yale. ${ }^{1}$ These lectures expounded the thesis that fault might, after all, be a sound basis for liability in automobile accident cases. And, perhaps more important, they contended that none of the myriad plans which had recently been proposed, and which in one way or the other sought their basis in some form of "risk spreading," could be supported. The breadth of the attack as well as the eminence of its authors would by themselves require a careful examination of this thesis. The fact that their position is essentially contrary to most current academic thought and, nonetheless, on the whole wrong makes such examination essential.2

What then in essence is it that Blum and Kalven are saying? The main outline of their analysis can be stated simply. First they say that there is no evidence that any automobile compensation plan can, out of its own economies, pay the added costs of non-fault compensation. If there were, and if these economies could not be achieved in another way, Blum and Kalven, like good classical economists, would accept the notion that such a plan was worthwhile. The gainers would be able to compensate the losers, and in some traditional economic sense a more

$\dagger$ Professor of Law, Yale University. Many of the ideas in this article were expressed by me at the Association of American Law Schools Torts Roundtable held in December of 1964. The other participants were Professors Addison Mueller of U.C.L.A., moderator, Robert Keeton of Harvard, and Walter Blum and Harry Kalven of Chicago. Professor Luke Cooperrider of Michigan was the chairman of the panel. I should especially like to thank the Walter E. Meyer Research Institute of Law, whose generous support is making possiblc my continued research in this area, and Jon Hirschoff, a student at the Yale Law School, whose help has been particularly significant.

1. Blum \& Kalven, Public law Perspectives on a Private Law Pronlem (1965) [hicrcinafter cited as BluM \& KALVEN]; originally published in 31 U. Cilr. L. REv. 641 (1964) as a revised version of the Shulman lectures.

2. I have not attempted in this short piece to examine all the arguments which Blutn and Kalven make. The scope of their work would make that impossible. I have attempted to concentrate on what, to me, is the key weakness in their approach. As a result, many of their elegant contributions and some rather surprising lapses are left unmentioncd. Since writing this article $I$ have received page proofs of a book review of BLUM \& KALvEN by Professor A. M. Linden due to appear at 53 CaLIF. L. REv. 1098 (1965). Professor Linden's piece more than fills many of these gaps. 
efficient arrangement would be available. ${ }^{3}$ There are in fact difficulties both with the way Blum and Kalven reach their conclusion that no plan can pay for itself, 4 and with the view that if it could that would end the matter. ${ }^{5}$ But for the moment I am willing to accept their premises.

Second they say: since no plan can pay for itself, we must next ask whether there is any theoretical justification for placing the total cost of accidents on a different group of people from those who currently pay. This question, in effect, assumes a totality of accident costs, and asks whether there is any reason for dividing them up in any way different from the present way. They describe the present way as one in which sometimes victims and sometimes involved non-victims bear all the loss, the decision turning on the rough and ready, but allegedly workable concept of fault. They, at times, depict this way as a vertical division of losses rather than a horizontal one, which would spread the loss among victims and involved non-victims leaving no one

3. BLUM \& KAIVEN 44-54; especially at 51.

4. One key to their conclusion is that adoption of any non-fault plan would result in increased claims consciousness, and that even if the economics of a plan could pay for current claims regardless of fault, they could not pay for the higher level of claims thus brought about. Id. at 46-54. There is, however, an interesting irony in their handling of this problem. At times their whole approach seems to be based on the "justice" of the current system. They say that it is better that worthy (non-fault) victims be fully com. pensated than that less worthy (faulty) victims (or victims injured by non-faulty drivers:) receive some recoveries at the cost of reducing the recoveries of "worthy" victims. Id. at 34. Yet when they discuss claims consciousness, they admit that there are many "worthy" victims-fault-free people injured by faulty drivers- who currently do not sue and do not recover. And it is the fact that these people (who in Blum and Kalven's terms ought to recover today) would probably recover under a plan (because of increased claims consciousness) which convinces them that a plan cannot pay for itself out of its own economies. In fact, if this were the only reason that a plan could not pay for itself, then Blum and Kalven would have given a good reason for a plan. For surely if a plan only costs more -and therefore reduces recoveries of "worthy" victims-because it gives recoveries to equally worthy victims currently left in the cold, and in addition manages to give something to other "less worthy" types, it would certainly meet Blum and Kalven's requirements. Actually there are other reasons to think that such plans could not pay for themselves just out of economies, and Blum and Kalven's conclusion that the money would have to come from somewhere is probably correct. Needless to say, $I$ find the whole concept of "worthy" victims hard to swallow and would continue to do so even if "fault" meant as much as Blum and Kalven think it means.

5. Economic literature is full of discussion of when a change is clearly an improvement. And while the start of such discussions is usually the statement that the winners an compensate the losers, that is just the start. Then arguments begin to rage over how to handle situations where compensation of losers, though possible, would not in fact take place, and how such situations relate to income distribution. While such anguments an reach a remarkable degree of mathematical elegance, sec, e.g., Mishan, Welfare Criteria for External Effects, 51 AM. Econ. Rev. 594 (1961) and works there cited, as lawyers we can, in this context at least, accept Blum and Kalven's formulation. 
as a $100 \%$ loser and no one as a $100 \%$ winner. Although their categorization is only approximately accurate, given the existence of insurance and their occasional flirting with compulsory insurance of drivers, it is, at least temporarily, acceptable.

Third, and most important, they answer no to the question they have posed; there is no better group of "payers," they say, at least under any plans so far presented. The reasons for this answer are really the core of their analysis. There are, they suggest, two significant grounds usually given for dividing accident costs on non-fault bases. The first is that we wish to compensate victims in such a way that no one is crushed by the loss. The second is that in some sense "economic theory" requires that one of the parties bear the costs it has caused. What they do not say is that the two bases of liability which follow from these grounds share a key element with fault: all three are derived from a common general goal-the reduction of total costs of automobile accidents to society. ${ }^{\circ}$ Fault, in theory, tries to reduce total costs by deterring specific conduct which is felt to be dangerous. "Letting the party which causes the cost bear it" attempts to decrease accident costs either by reducing the cost-causing activity by making it more expensive, or by inducing the introduction of safety devices to the extent that they cost less than paying for the damages which they prevent. "Spreading the loss broadly" attempts to reduce costs in a secondary sense. It does not, like the first two bases of liability, seek to reduce the number or gravity of accidents, but by spreading the burden of accidents it attempts to reduce the bad effects that accidents havetheir secondary costs. ${ }^{7}$

At first glance then, the other bases of liability would seem to merit at least as much adherence as fault. ${ }^{8}$ But Blum and Kalven decide otherwise. The reasons why they reject each are quite different. They discard risk spreading (compensation of the victim) as a goal of accident law because the same result can be accomplished better through social insurance paid out of general taxes. This solution is better than

6. See Calabresi, The Decision for Accidents: An Approach to Nonfault Allocation of Costs, 78 HARv. L. REv. 713, 713-16 (1965). On the relation of fault to this gencral goal cf. Holmes, The Common Law 76-77 (Howe ed. 1963).

7. Blum and Kalven, among others (e.g., Calabresi, supra note 6 at 714, 734), fail at times to keep in mind that it is minimization of total accident costs, not minimization of accidents, which is the goal. See, e.g., BLuM \& KALvEN 61. Usually minimization of accidents is just used as a short-hand way of saying minimization of accident costs. Occasionally, however, that short-hand may lead to conclusions which would be harder to justify if the goal of minimizing costs and not just accidents were kept in the forefront. Sec, e.g., Bl.UM \& KALven 63.

8. Each is, in a sense, a sub-goal of the general goal of minimization of accident costs. 
any accident-law solution because it is more efficient (cheaper), because it makes both the degree of burden (taxes can be adjusted) and the degree of compensation (payments can too) exactly what we want them to be and because we can choose the payor and payee in accordance with their means (with the goal of compensation-spreading in mind), whereas accident law at best hits classes of good risk bearers but might include a fair number of bad ones, as well. Of course, if risk spreading is the goal, any serious injury or disease is worthy of the same treatment, and the problem seems to become, as Blum and Kalven view it, one of "poverty" or "distribution of wealth" and not at all one of accidents. ${ }^{9}$

Blum and Kalven reject allocating the accident cost to the party which "causes" it because, they contend, any accident cost is in fact caused in an economic sense by all those involved in the accident. Since there is no meaningful way of deciding to what extent a carpedestrian accident is in fact a cost of driving or walking, we cannot hope correctly to burden one activity with its proper share of the cost in order to reduce it or to induce it to introduce safety measures to a proper degree. Therefore, they conclude, economic theory does not give us a workable standard for allocating losses.

Since the goals of risk spreading and letting the party who causes the cost bear it are either meaningless, or can best be accomplished outside of accident law, we are left, Blum and Kalven suggest, with fault, which, in a rough and ready way, divides losses according to a sense of justice (which, they assert, we have) and, to a degree, reduces total accident costs through specific deterrence. They never really ask -as they do with compensation-whether the goals of fault can better be accomplished outside of accident law. And they treat on the whole unsatisfactorily the questions whether there is any meaning to the sense of justice which fault supposedly vindicates, and whether fault in fact accomplishes any specific deterrence.

So much for the thesis. What does it in fact show? The first thing to note is that, rather unintentionally, the one "plan" which comes out best as a result of Blum and Kalven's dissections is not the current fault system-which is left alive, if cadaverous, more for want of a better way than from its own merit-since its "merit" is left largely unexplained. Rather it is social insurance, which emerges as a cheap and effective way of meeting a problem which Blum and Kalven admit exists, that of compensation, or spreading of losses.

And this result is not surprising. For if we deny a meaning to what

9. See, e.g., BluM \& Kalven 37-38, 41-43, 83. 
I have elsewhere termed resource allocation, or general deterrence, as a reason for accident law, ${ }^{10}$ if we feel that accident law has no part to play in influencing whether manufacturers, for instance, should use a more expensive but safer material rather than a cheaper more dangerous one, or whether teen-agers should drive as much as 45-yearolds, then there is mighty little reason for accident law at all. It would then be true that the only goals of the law in this area would be a) deterring specific acts of wrongdoing (acts we wish to forbid even to those willing to pay for the costs which result), ${ }^{11} \mathrm{~b}$ ) satisfying our "sense of justice" and c) compensating victims. The first two would hardly require the existing massive apparatus of torts and fault. They would best be handled outside of torts law by some more modern semi-criminal device involving, perhaps, non-insurable fines. ${ }^{12}$ The last goal would,

10. Calabresi, Some Thoughts on Risk Distribution and the Law of Torts, 70 YaLe L.J. 499, 502 (1961) [hereinafter cited as Calabresi, Risk Distribution]; Calabresi, supra note 6, at $718,725 \mathrm{n} .18,742$.

11. We do not permit the individual to exercise independent judgment on the valuc of drunken dxiving by offering to pay for all the damage he causes while intoxicated. But even under our present fault system, such specific deterrence is attempted largely through the criminal law. See generally Calabresi, supra note 6, at 716-21.

12. I assume that, to the extent that we want to deter specific acts directly, a noninsurable fine will be more of a deterrent than a potentially large but fully insured torts judgment. I assume also that at least within the context of actual accidents it would not bc as expensive to levy such fines as to go through civil torts trials. We might incur added expense if we extended semi-criminal fines to situations where no accident had occurred, for then the cost of discovering the situation would be added. But fault-torts makes no attempt to deal with such questions today. The proper comparison is between specific deterrence accomplished by fault-torts today and the specific deterrence which would bc accomplished by having substantial non-insurable fines levied on wrongdoers in accident situations. If we then wanted to expand this deterrence, at added cost, to non-accident situations, that would be another matter.

I am, of course, weaseling to some extent when I talk of a "more modern semi-criminal device." To discuss the form of such a sanction, the procedure for applying it, and its relation to current criminal law would require, at least, a full article. But enough writers have discussed the concept that it is not unfair to suggest that some form of that device may provide a better answer to specific deterrence than is given by fault and insurance in torts today. See, e.g., Blum \& Kalven 63-64.

The question remains, however, whether such a device would satisfy our sense of justicc as fully as fault liability. This I find hard to answer, for I do not fully understand the term "sense of justice." To many people it seems to mean something in the nature of revenge, beyond deterrence and compensation. It is hard for me to swallow this in straight criminal situations, and, of course, even harder in torts situations. But even assuming some meaning for it, would we not get more "adequate" or "just" revenge if the wrongdoer were assessed according to his wrong and not according to chance and the size of his insurance policy? On the receiving end, too, one could have a different scale of compensation if one wished, depending on the innocence of the recipient. But why should com. pensation depend on the relative innocence of the victim and the particular injurer, and on the injurer's particular insurance coverage? Surely our sense of justice has advanced somewhat beyond the rather medieval "duel" stage. 
as Blum and Kalven suggest, best be handled through social insurance rather than through our cumbersome system of torts laws. Since Blum and Kalven reject the general deterrence thesis and make only weak arguments for the necessity of retaining our current fault system, it is only natural that the one conclusion most will draw from their discussion is that we are well on our way to generalized social insurance, despite Blum and Kalven's seeming personal distaste for the loss of freedom that system may entail!

What then are the problems with their analysis? As I see it there are two major problems, and they are related. The first, and more specific one, is that their rejection of "allocation of resources," "general deterrence" or "economic theory" (all really words for the same thing) as a guide of any usefulness at all is premature. This is far from saying that "general deterrence" presents the answer to the problem. It is only to say that despite Blum and Kalven's attack, general deterrence is, as I hope to show, an element which must be given consideration together with compensation and the "specific deterrence" supposedly induced by fault liability in arriving at a sensible solution. The second problem is that Blum and Kalven reject most proposed "plans" because they do not do as good a job of meeting a specific goal as an extreme or ideal solution; but these plans are never examined as ways of accomplishing a complex mixture of goals. Each plan is rejected because it does not do perfectly some one thing we desire, although it may do the combination of things we want pretty well. The current fault system is, of course, not subjected to a similar test. For example, plans designed to increase loss spreading or compensation are ruled out because "social insurance" can do it better (given social insurance, all are equally good risk bearers). But social insurance could equally be rejected for failing to effectuate some of the deterrence goals we wish of accident law. And the key question, whether fault or any given non-fault system best accomplishes the mixture of goals we in fact want, is never really asked!

I have said that these two problems with the book are related, and before I discuss them in detail, it may be well to explain generally what the relationship is. In the first place, the more goals we want accident law to accomplish, the more likely the kind of unilateral comparison Blum and Kalven engage in will be misleading. If general deterrence is added to specific deterrence, compensation and undigested "justice" as an aim of tort law, an analysis which rejects one plan because it does not compensate as well as social insurance, and rejects another plan because it does not give us as good undigested "justice" as 
fault might, becomes even less satisfactory. The more valid aims we have, the more we must look to see which system or combination of systems does the best job of reconciling them all.

The second aspect of this relationship follows from the fact that the validity of "general deterrence" as a goal of tort law may depend in part on the existence of a variety of other valid goals. Blum and Kalven say that economic theory can not tell us whether it is better for cars or pedestrians to bear the cost of car-pedestrian accidents. Even if that statement were completely true (which it is not), ${ }^{13}$ if economic theory suggested no more than that the cost should be borne by cars or by pedestrians, then, although fault might be as good a ground for dividing the cost between them as any (from a general deterrence point of view), social insurance, which removes the cost from both pedestrians and cars, would not! Thus, if compensation motives led us to remove (externalize is the economists' term) part or all of the cost from both pedestrians and drivers and cover it by social insurance, we would substantially violate the goal of general deterrence. In short, we might find that fault failed because it gave inadequate compensation, while social insurance failed because it removed the cost from the combined cost causers (pedestrians and drivers) and, therefore, gave no general deterrence. Instead, a combined plan which picked the best loss spreader between pedestrians and drivers, although not giving as good compensation as social insurance, or any better general deterrence than fault, ${ }^{14}$ might still give the best combination of both.

I do not mean this to be the answer, not yet at least. For I have left out of the mixture those goals which fault supposedly accomplishes best-specific deterrence and gratifying our sense of justice-and if I were to support a system on such analysis, I would be guilty of the same fault of which I accuse Blum and Kalven. The only conclusions to be derived from the above analysis at this stage are: 1) it is incorrect to reject systems which seek to accomplish a variety of goals because a single-minded system can meet one goal more fully; and, conversely, 2) a goal which by itself may not be so capable of definition as to determine a single perfect solution may nevertheless be clear enough and important enough to rule out some solutions, and therefore to militate for mixed rather than single-minded systems.

13. See Calabresi, supra note 6 , at 725-42, especially 726-27 and 734.86.

14. I have argued elsewhere that various combined non-fault plans would, in fact, give better general deterrence than fault, because they would tend to deter activitics prone to serious accidents rather than just activities prone to fault-caused serious accidents. Calabresi, supra note 6, at 719-20. I still hold to that, cf. note 37 infra, and am only taking the "weaker" position here, arguendo, for the sake of remaining close to Blum and Kalven's argument. 
These conclusions would be enough for a book review and perhaps I should stop here. But to do so would leave substantially unanswered the specific criticisms which Blum and Kalven make of "general deterrence" or, in their words, of "economic theory," as a guide to allocation of losses. There is no need to go to great length in reiterating what the "general deterrence" thesis is. ${ }^{15}$ Essentially it is the notion that in our society what is produced is by and large the result of market choices by individuals. These choices are influenced by the relative prices of competing goods. To the extent that these prices reflect the costs of producing the product involved, people get as near to what they want as is possible in a fallible world; but to the extent that these prices understate the actual cost to society of producing a product, more of that product gets made and bought (relative to other goods) than we in fact want, and unnecessary costs are undertaken. And finally, accident costs are as much costs to society and as worthy of being considered in deciding what goods we want as, say, the cost of the metal it takes to make a product. Specifically, the thesis holds that although, for instance, we may not want the safest possible product, we do want the manufacturer to choose a means of production which may be somewhat more expensive in terms of materials used if this expense is made up by savings in accident costs. Similarly, although we do not wish to abandon cars altogether (they give us more pleasure than they cost us-despite accident costs), we may, if we are made to pay for car-caused accidents, drive less, or less at night, or less when we are of accident-prone ages, or with more safety devices, than if we are not made to pay for accident costs when we decide to use a car. I call this thesis general deterrence, because it seeks to diminish accident costs not by directly attacking specific occasions of danger, but (like workmen's compensation) by making more expensive those activities which are accident prone and thereby making more attractive their safer substitutes.

Blum and Kalven divide general deterrence into two areas: situations arising from injuries where the choice of loss bearers is between related parties-for example, buyers and sellers-and situations arising from injuries where the choice of loss bearers is between independent parties. The first is exemplified by a workmen's compensation

15. See generally Calabresi, Risk Distribution at 500-17; Calabresi, supra note 6, especially at 719-20.

This thesis has, as I have pointed out elsewhere, many limitations. These involve, among others, the existence of monopoly power and the problem of income distribution. See Calabresi, Risk Distribution 503, \& n.17, 507-14. These limitations would be enough to preclude making general deterrence our sole goal. But as I tried to show in the above article, they do not render it invalid as one of our aims. 
accident, a Vincent $v$. Lake Erie situation, ${ }^{16}$ or a simple products liability-with privity-case; the second by a car-pedestrian accident. Blum and Kalven conclude that, on the whole, it makes no difference (in terms of economics) who bears the loss in the first case, and that economics can give no guide as to who ought to bear the loss in the second. Needless to say, while I agree fully with their division of the problem into what I have elsewhere called "bargaining" and "nonbargaining" situations, I do not agree with their conclusions as to the relevance of economics to each.

The first and easier case is the bargaining situation. Blum and Kalven contend that it makes no difference which of the two bargaining parties bears the loss. And, in theory, they are correct. How the theory works has been clearly stated by Blum and Kalven in their book and perhaps less clearly by me in an earlier article, ${ }^{17}$ so there is little point in restating it fully. The short of it is that the price ultimately established between the parties to the bargain will-under perfect competitionnecessarily reflect who bears the risk of loss and, therefore, the same share of the loss will be borne by each regardless of who the original loss bearer is. Moreover, the party who is made to bear the loss initially will try to minimize his loss (if minimization is possible) by installing safety devices or by dealing only with parties who do, whichever is cheaper. Consequently, the cheapest way of minimizing the loss will result, whoever the initial risk bearer is. The use of safety devices is, of course, only one example of how such losses may be minimized.

That this theory is an insufficient answer is patent. If nothing else, the effect workmen's compensation had on industrial accidents (a classic "bargaining situation") made this clear once and for all. Part of the reason for this insufficiency is, as I have attempted to say clsewhere, that the theory presupposes two things: a) the equal ability of the parties to the bargain to estimate and value the risk of accidents properly and to act on their evaluations, and b) the equal ability of the parties to insure-or self-insure-at an equal cost. In addition, the theory excludes a third thing: c) that the initial placing of all or part of the loss on one of the two bargaining parties rather than on the other may result, for political, compensation or other reasons, in the removal of this portion of the loss from both bargaining parties, with the result that the pressure toward minimizing the loss would be lost. In

16. Vincent v. Lake Erie Transp. Co., 109 Minn. 456, 124 N.W. 221 (1910). Defendant kept its vessel tied to plaintiff's dock during an "unforeseeably" violent storm, and was held liable for damage to the dock.

17. BLUM \& Kalven 58-59 (the watch case). Calabresi, supra note 6. 
practice, the two assumptions made by the theory are often invalid, and the excluded situation is very real. And whenever one of these contingencies occurs, "economic theory" or "general deterrence," taken not as an exercise in economic "model" making, but as a practical tool, suggests very definite preferences as to loss bearers in bargaining situations.

Economic theory suggests, first of all, that the party who can better evaluate the risk of accidents is the better loss bearer, because his evaluation will bring about a more accurate determination of the point up to which changes to avoid accident costs (such as safety measures or reduction in an activity) are cheaper than the accident costs which would result without these changes. It suggests, secondly, that the party who can insure or self-insure more cheaply is the better loss bearer, because the other party would be influenced, in making the decision as to the changes suggested above, by an unnecessary administrative cost, the extra cost of providing him with insurance. Finally, it suggests that the better loss bearer is the party whose initial bearing of the liability does not result, for compensation or other reasons, in removal of the loss from both parties. For such removal would destroy the incentive to adopt the changes previously mentioned. ${ }^{18}$ These three preferences, of course, will not necessarily be consistent in any given case. But they each represent criteria based on general deterrence which must be taken into account in a deciding who is the better loss bearer in a bargaining situation.

Blum and Kalven, although starting from the position that generally it makes no difference in a bargaining situation who the initial loss bearer is, do admit one, and only one, reason why this theory does not work perfectly. This reason, somewhat different from any of the three that I have suggested, has some validity, but is inadequately analyzed by them. The reason given by Blum and Kalven for doubting

18. This result would occur whenever one of the parties (on whom all or part of the loss is placed) received assistance (such as a government subsidy) in paying for the portion of the loss initially placed on him. To the extent that a party received such assistance, he would not consider minimization of the loss worthwhile, since he would be paying for the minimization (i.e., he would pay for the safety devices, or would pay more by dealing only with parties who used safety devices), while only the assisting party' (e.g., the government) would benefit by the reduction in loss. The assisting party might, of course, try to bring pressure on the assisted party to minimize the loss-query, however, how expensive and how effective such pressure would be. Cf. Calabresi, supra note 6, at 727-28.

The result under discussion assumes, it must be remembered, only assistance which is triggered by the placement of loss upon the party, not subsidies generally. A party receiving. for example, a yearly subsidy, which is not affected by his accident costs, would react exactly like a non-subsidized party. 
this theory is this: "Placing liability on the [manufacturer rather than the victim in a product liability, industrial accident, or other bargaining case] is tantamount to compelling [potential victims] to buy insurance against the loss through paying a higher price." 10 Moreover, they suggest, this insurance necessarily fails to take into account the different accident proneness of different potential victims and therefore makes the safe user pay as much as the unsafe one. At first glance this argument seems compelling. But it turns out that the first point, "compulsory insurance," is, strictly speaking, false, and the second, while it does suggest a valid criterion for determining the better loss bearer in a bargaining situation, names it as the sole one, when it is only a criterion of the same type and general significance as the three I have suggested.

It is of course true that if we make manufacturers of a product compulsorily liable with no right to "opt out" (exculpate themselves) for a price discount, the user will, in effect, be forced to insure against accidents. Part of the cost of all accidents will be included in the price he pays, and he will be covered if he is the one hurt. That is what insurance is. But it is equally true that if manufacturers are not liable and have no right to "opt in" to liability for a higher price (indemnify the user), then manufacturers will, in effect, be forced to insure against accidents, and users will be the insurers. ${ }^{20} \mathrm{~A}$ manufacturer (according to the theory Blum and Kalven accept) will have to charge less for the product than if he were liable, since users will be aware of the risk they take in buying the product. This reduction in price represents the "cost" of the "compulsory" insurance to the manufacturer.

This case, where manufacturers cannot assume liability, strikes us as unlikely, and in practice perhaps it is. For we do not usually think of manufacturing situations where we would not allow the seller to agree to indemnify the buyer. The typical manufacturing situation, however, is just one selected example of the bargaining problem. Consider, instead, a large number of small farmers selling whent, which occasionally explodes, to the gigantic "Incorporated Millers Company"-or more realistically, small parts manufacturers selling to a

19. Blum \& KaLven 59. See also note 23 infra.

20. The users could, of course, farm out the risk; that is, they could insure with parties outside the bargain, in short, insurance companies. Similarly, if the manufacturer were originally held liable, he too could farm out the risk. These facts in no way affect the analysis in the text, for the insured is, in either case, compelled to be insured; they just mean that the original insurer is not compelled to be a final insurer. It is still truc, however, that the cost of avoiding being a compulsory insurer, i.e., the cost of furming out the risk as against self-insuring or taking a lump loss, is, and ought to be, an important factor in deciding who the better risk bearer is. 
large industrial user. ${ }^{21}$ In these cases the notion of forbidding the seller from "opting into" liability (from agreeing to a "form" indemnification contract), with the resulting "compulsory insurance" of the seller, seems quite plausible. The cases of the farmers and the small parts manufacturers are, in fact, exactly the same as Blum and Kalven's reversed. The only difference is that in my examples we may want to make insurance of the seller compulsory, while in Blum and Kalven's example we seem to want to make insurance of the buyer compulsory. In either case it is our decision to exclude contractual arrangements designed to shift the initial loss from one bargainer to the other which makes the insurance compulsory, not the fact that the loss is originally placed by law on one or the other..$^{22}$

The fact of the matter is simply this-whenever we determine, as a matter of law, which of two bargaining parties will bear the initial undivided cost of an accident, and forbid the shifting of that liability to the other in exchange for a fee, we are compelling the party who is not held liable to insure against the loss with the party who is liable.23 This is not to say that we are indifferent as to which party we wish to compel to insure, or that we are indifferent as to whether we wish to compel insurance at all or to make it optional by allowing exculpatory or indemnificatory clauses. The point is only that the argument which Blum and Kalven make from compulsory insurance is false, for whether compulsory insurance results from a liability scheme depends not, as they say, on which party is held liable, but on whether once we decide to hold one party liable in the first instance (for any of the reasons I have previously suggested) we let that party exculpate

21. Cf., United States v. New York Great A \& P Co., 173 F.2d 79 (7th Cir. 1949), also a monopsonistic situation in an area where we usually think and speak in terms of monopolistic power.

22. Opting in may be different from opting out. Opting in sounds as if the assumer of liability has a greater awareness of what he is doing. (But imagine my "Incorporated Millers Company" using a form contract requiring opting into liability.) In any case, this difference is but another illustration that knowledge or awareness of risk may affect the choice of whom we wish to hold initially liable and whether we wish to allow such a party to exculpate himself (Cf., the criteria I suggest as relevant, text accompanying note 27 infra.)

23. Strictly speaking, "held liable" is not used in the normal sense. I am using the term to identify the party who under the law bears the initial undivided loss, whether that party is the party who is originally injured or the party who through a legal judgment must compensate the injured party and thereby becomes the financially injured party. I use the term this way to emphasize the fact that whether the originally injured party or some other party is made to bear the undivided loss, in the first instance, is the result of a legal judgment, a "holding liable," and not of metaphysics. Failure to recognize this fact leads easily to the error Blum and Kalven make-that compulsory insurance in this area is a one-way street. 
itself-that is shift the risk of undivided loss to the other-for a price. Nor does the fact that we are more likely to let one party exculpate itself than the other change my point at all. For this fact just suggests that reasons not discussed by Blum and Kalven for assigning liability in a bargaining situation (such as unequal awareness of risks or unequal bargaining power) are sufficiently strong to impel compulsory insurance of the non-liable party.

This argument leaves unanswered, however, Blum and Kalven's point that the compulsory insurance which comes about in a bargain. ing situation is a particularly noxious one since it charges all those who are insured the same premium. All users of Brand X (which occasionally explodes) pay the same additional amount for the product once it is decided that Brand $\mathrm{X}$ will compensate the injured buyer, even though people over 45 are more likely to suffer serious injury than nimble 33 year-olds. But why would all parties pay the same amount for this insurance? In the wonderful world of Blum and Kalven, where all parties know and evaluate all risks equally well, and insurance costs stand in the same proportion to risk for all parties-in the world of their theory without my limitations on it, in other words-there would be no such equality. ${ }^{24}$ The manufacturer of Brand $\mathrm{X}$ would

24. If Blum and Kalven are troubled that in some cases compulsory insurance results in the same premium to each insured, they should (in the wonderful world of their theory) be dismayed at the very existence of insurancel For differentiation in prcmiums is only movement along a spectrum which begins at total social insurance (no differentiation among risks) and ends at the absence of insurance (total differentiation among risks, or total predictability). At one end there is perfect loss spreading; at the other there is perfect general deterrence, since each individual undertakes each act fully aware of its costs and perfectly willing to pay those costs. In the latter case, there may still be "intertemporal insurance" through saving but never "interpersonal insurance."

In a world where predictability is limited, however, each individual must either undertake actions at the risk of their costing more than he had anticipated, or be willing, to some extent, to pool his risks with those of others. He may sometimes even be compelled to pool his risks; see text preceding note 23 supra. This pooling may take place through farming the risk out to an "insurance company," or through dealings between a group of parties "not held liable" and parties "held liable." (See note 23 supra.) (The latter situation is illustrated by Blum and Kalven's watch case. See note 17 supra.) If an individual wishes to pool his risks, he can never insist on total differentiation in premiums (that would mean the absence of risk pooling), or on the particular differentiation which suits him; he must accept that differentiation in premiums which is set by the insurance company or by the party "held liable." Of course, under relatively pure competition the insurance company or the party held liable would have to differentiate so long as greater differentiation was worth more to the insureds or non-liable parties than it cost the insurer or liable party. In all cases, moreover, the amount of differentiation in premiums, or movement along the spectrum I have described, must be related to the costs of such movement faced by the insurance company or party held liable. Why Blum and Kalven should be so concerned about lack of differentiation when a "party held liable" is concerned, and not when an "insurance company" is involved, is not clear to me. 
charge different users different prices depending on their accident proneness. He would, in effect, charge them different insurance premiums according to their risk categories. The fact that the manufacturer does not distinguish among his purchasers in this way is simply a sign that the distinction is not worth the cost, a not unusual fact in insurance. Indeed, if Brand X were used in making toilet paper (hardly any explosive potential) and airplane bodies (very high explosive potential), and if the maker of Brand X were the party held liable, we can be sure that the prices charged to the two types of buyers would be very different and would reflect the different accident proneness of the uses.

The reverse is similarly true. If users of goods are uncompensated for injuries-that is if manufacturers are "forced" to insure with their buyers-and if different manufacturers have different accident records, they may or may not be able to command different prices for their goods. This ability will depend on how significantly different their accident records are and on the feasibility of having a price structure with differing prices. If the manufacturers can command different prices, then the case is like Brand X toilet paper and airplanes reversed. If they cannot, then it is like the "horror" Blum and Kalven pose, for here the safe manufacturer (in Blum and Kalven it was the safe user) is forced to pay the same "compulsory insurance premium" as the accident-prone one.

Having said all this, I must admit that Blum and Kalven have a point-if a small one. It is certainly true, in fact, though not in Blum and Kalven's theory, that in most bargaining situations one of the parties is better able to differentiate than the other. It may be more difficult or expensive for manufacturers who are held liable to charge different prices to users in accordance with the latters' accident proneness, than it is for users who are held liable $e^{25}$ to command different prices from manufacturers according to the manufacturers' accident

We may make a collective judgment that we want more general deterrence, or, instead, more loss spreading, than is provided at the equilibrium point reached on the spectrum through private dealings. If so, we can take action resulting in more or less differentiation. as the case may be. Consider, for example, subsidized special risk categories to enable employment of physically handicapped, and hence accident-prone, workers. But we cannot have both more loss spreading and more general deterrence; hence the constant tension between them. Of course, the point on the spectrum desired by society might well be the same as arrived at through the process of private decision making described above. Indeed, the more we accept the basic postulates of "free market" economy, the more this is likely to be so. I am indebted to Mr. Jon Hirschoff for the thoughts awkwardly expressed by me in this footnote.

25. See note 23 supra. 
proneness. ${ }^{26}$ If this difference exists in fact, then a small argument (based on general deterrence) exists for user rather than manufacturer liability. But it exists despite the theory which says that it makes no difference who is held liable, as the argument is of exactly the same nature and weight as the three arguments I suggested previously for deciding who in a bargaining situation ought to bear the loss. Indeed the criterion Blum and Kalven suggest may be no more than a restatement in a slightly different context of one of the criteria I suggested: "which party can more efficiently insure against the loss." But whatever the context, this is not the sole criterion. For surely it is equally important to know whether the various manufacturers are better aware of the accident risks involved in their products than are the users, as it is to know whether they can distinguish the accident proneness of users more easily than the users can distinguish the accident proneness of the manufacturers.

In other words, in theory it makes no difference, for general deterrence, which of two parties to a bargain bears the accident costs which may result. In practice it might also make no difference (usually when the bargainers are of approximately equal size, number, expertise and wealth). But it may make a great deal of difference. Among the factors which operate to determine who is the better loss bearer from a general deterrence point of view are: 1) which of the parties can better evaluate the risk involved; 2) which of the parties can better evaluate the accident proneness of potential parties on the other side; 3) which of the parties can better let this knowledge, when significant, be reflected in the prices it can command; 4) which of the parties can more cheaply insure against the liability; and 5) placing liability on which of the two

26. This is not unlikely in what we think of as the normal situation with respect to manufacturers and users, because of the numbers involved (it may be casier for many users to inform themselves about the products of a few manufacturers than it is for the manufacturers to inform themselves about the habits of each user), and perhaps because it may be easier to determine characteristics of products than to determine habits of individuals. But manufacturing cases are only one instance of the "bargaining" situation. And, especially in non-manufacturing cases, the person we think of as the uscr may be in the opposite position. See, for example, Vincent v. Lake Erie Transp. Co., supra note 16, where the dock owners could probably estimate with relative ease the damage which a given boat would inflict to a dock during a violent storm, while boat owners might find it difficult to say which dock would most likely be hit by a violent storm.

The passage of time may affect our estimate. Whereas it was once casicr for the employer (held liable for injuries to employees) to adjust the wages of the cmployec according to his safety record than it was for the employee (made to bear the cost of his injurles) to command higher wages from more accident-prone employers, today in industries where labor unions are strong the reverse might even be true. $C f$. Calabresi, supra note 6 , at 728 n.22. 
parties is less likely to cause the loss to be removed from both, for compensation or other reasons. ${ }^{27}$

So viewed, the "bargaining" situation, far from being the throw away which Blum and Kalven make it out to be, becomes a situation where general deterrence gives definite guidelines. And Blum and Kalven's ultimate conclusions on the bargaining case show the error of not keeping these general deterrence guidelines in mind. For they conclude that when you deal with a bargaining case, in theory it does not matter who bears the loss, and in practice it matters only in the sense of finding who is the more readily available and cheaper insurer. Furthermore, they say, there is no reason to believe that the manufacturer is a better loss bearer than the consumer, because social insurance can make the consumer a better insurer than the manufacturer. The trouble is that social insurance removes the cost from both the bargaining parties and, according to the theory Blum and Kalven accept, it is important to the diminution (general deterrence) of accident costs to keep these costs on one or the other. The relevant question, then, may not be who can insure more cheaply in an absolute sense, but what allocation of liability results in finding the cheaper insurer while keeping the cost on the bargaining parties. The answer is not social insurance, but may be manufacturers' liability. I say may be, because general deterrence guidelines cannot by themselves determine where we want to place liability. We cannot, however, ignore these guidelines in comparing how well different systems or plans (including fault) meet our combined complex of goals.

The more difficult case Blum and Kalven pose is that of non-bargaining parties, such as the car-pedestrian accident. Here Blum and Kalven are prepared to say that it may make a good deal of difference, from a general deterrence point of view, which of the two parties bears the loss; but they claim economic theory is of no help at all in deciding this question. They first, properly I fear, reject the ingenious attempt of Professor Coase to resolve this case into the bargaining case. ${ }^{28}$ They

27. See also note 22 supra.

28. Professor Coase suggested the possibility of independent parties involved in accidents or other joint-cost causing activities entering into bargaining relationships and concluded that where the cost of establishing such relationships was not too great the independent situation would, in theory, resolve itself exactly as the bargaining one did. Blum and Kalven, however, and indeed Coase himself, feel that the practical limitations on such "artificial" bargains are significant enough to exclude their being the answer. Bluss \& KALVEn 6I-62. See generally Coase, The Problem of Social Cost, 3 J. LAw \& Econ. 1 (1900). I agree-and feel that there may be some theoretical limitations as well. Sce Calabresi, supra note 6, at 724-31 and accompanying footnotes. This is too bad, because were Cosse's theory frequently workable, the guidelines for liability derived in the bargaining case 
then assert that since we do not know the extent to which the costs of car-pedestrian accidents are due to cars and the extent to which they are due to pedestrians, economics can give us no way of dividing the costs of these accidents that is more precise than fault.

But once again, I think, Blum and Kalven have moved too quickly. For again our general deterrence motives do tell us that, in theory, even if we could not tell what part of the cost to put on cars and what part to put on pedestrians, it would be better to put the cost on one or the other, or partially on both, than to externalize it from both and make it a general cost of living (as social insurance would do). Indeed economic theory would go further and say that the more we can sub-categorize (the more we can put the cost not just on "cars" but on old cars or old cars driven by people under 21, etc.), the more adequate general deterrence we get. ${ }^{20}$ Of course, since it costs money to sub-categorize, we shall finally reach the point at which the added general deterrence achieved is not worth the cost of the added subcategorization. ${ }^{30}$

If, moreover, we knew that we wanted the cost to be distributed among the smallest sub-categories of pedestrians or drivers which can efficiently be drawn, then we would tend to rule out those loss allocation systems which, for either compensation or political reasons or for just practical reasons of how the insurance industry works, tend to put the cost on broad categories rather than small categories, or ultimately remove it from both parties to the accident and put it on the broadest category of all, "the taxpayers." A few examples may help. Suppose that we have no theoretical guidelines indicating whether pedestrians or drivers ought to bear the costs of car-pedestrian accidents. Suppose also that we know that drivers can insure cheaply against such accidents at prices which relate to their driving record and relevant characteristics (age, type of car, etc.), but that pedestrians can insure

would apply here as well. As it is, more work is needed, though it still helps to know that egregious mistakes made in assigning liability in non-bargaining situations may, at least in part, be mitigated through Coasian "deals" between independent partics.

29. See generally Calabresi, supra note 6, at 733-34.

30. Among the costs of sub-categorization are those of fact-finding and record kecping. Whenever the parties involved are benefited (or suffer loss) by virtuc of their category, the cost of determining the facts on which to base categorization is likely to be substantial, because one cannot rely on statements of facts by the parties. Compare the problem under workmen's compensation of whether an injury is work-related.

The point at which added general deterrence is not worth the cost of sub-categorization may even be at social insurance in some areas. See ConAkd et al., Auromontle Accident Cosrs and PAYMENTs, 52 (1964), and Conard, The Economic Trealment of Aulomobilo Injuries, 63 MICH. L. REv. 279, 289-91 (1964). 
cheaply against such accidents only by taking out broad "all accidents of living" policies. Placing the cost on drivers would in this situation tend to cause a proper general deterrence effect (it would influence the amount and type of driving in relation to pedestrian accidents caused), while placing it on pedestrians would not result in general deterrence. Though the theory would not tell us in the abstract which party ought to bear the loss, the theory would, in practice, tell us that drivers should.

We would reach the same result if placing the cost on pedestrians would not affect the amount or type of walking chosen because walking is (let us assume) an activity which is virtually fixed and has no safer substitutes. The pedestrian would, therefore, have no alternative choices if some forms of walking were made more expensive than others. ${ }^{31}$ If driving, instead, were more flexible, or had more substitutes, drivers would once again be better loss bearers. Furthermore, even if walking were not "fixed" but we wanted it to be fixed and unaffected (for various political or philosophical reasons) then we could best minimize car-pedestrian accidents by placing the loss on drivers.

Finally, and most important of all, if placing the loss on pedestrians results in such an unpalatable situation, from a compensation point of view, that the loss is removed from the pedestrians, and is shifted to a general social insurance fund, then we know that from a general deterrence point of view the pedestrian is a poor loss bearer. If, in addition, putting the loss on drivers has no similar effect, then general deterrence tells us quite clearly that the driver is the better loss bearer. ${ }^{32}$

31. The assumption now is different from that in the previous paragraph. I am assuming here that pedestrians can insure against car-pedestrian accidents at prices geared to their individual characteristics as pedestrians. The new assumption is, however, that this will have almost no effect on "walking."

32. It may not be readily apparent why, if economics cannot tell us how to divide pedestrian-car accident costs between pedestrians and cars, it is better, from a general deterrence point of view, that cars bear all the cost than that cars bear part and the rest be removed from both. The reason we have difficulty in determining a proper division of costs between the two is that we cannot say how much the presence of cars, as against a substitute, adds to the cost of walking; and how much walking, as against a substitute, adds to the cost of cars. All we know is that together they have certain costs. Sec Calabresi, supra note 6, 725, 737-39. It is probable that the best way (the cheapest from the point of view of society) of reducing these costs would be to affect both ars and walking somewhat (both as to the amount of each which is done and as to the way in which it is done-the latter means driving new cars rather than old, driving by older people, etc). But vic do not know, at least on the Blum and Kalven assumptions, how much we should try to affect cars and how much walking. Since we do know, however, that together they cost society a certain amount, we can say that, from an allocation of resources or general deterrence point of view, we are always better off if we reduce or alter the combined activities, either jointly or severally, up to the point where people would rather pay for the accident costs than suffer the reduction or alteration. Up to that point, the clange 
This last example is particularly germane in view of the conclusions which Blum and Kalven reach with regard to the problem of compensation (risk spreading) in the context of automobile accidents. They pose the question: "Are motorists as a class superior risk bearers to the tax paying public?" "The very existence of social security indicates that the answer is obviously no." 33 But if it is only a form of social insurance which can make auto victims as good risk bearers as motorists (from a compensation point of view), then, in practice, from the point of view of general deterrence or economic theory, motorists are much better loss bearers than pedestrians, since putting the loss on pedestrians means putting the loss outside the motorist-pedestrian pair. Once again, Blum and Kalven's error is to talk general deterrence just long enough to show that it gives no complete answer, but to forget, when the discussion turns to compensation, the indications general deterrence is able to give. For if the choice is among three types of systems, the first of which gives general deterrence and some compensation (as in a motorist liability plan), the second of which gives optimal compensation but no general deterrence (as in social insurance) and the third of which gives general deterrence but inadequate compensation (as in a pedestrian liability, or a fault-based plan), we may

"costs" people less than the accidents avoided, and so is worth doing. It is worth doing, moreover, even if the change is all at the expense of one activity and a chcaper (leas painful) change could be accomplished in theory by affecting both. For this last premise does not deny that the original change "cost" people less than it saved them; all it shows is that a theoretically better change was possible. But this theoretically better change is, under the original assumptions, not available in practice. For the situation we are cxamining is one where whatever part of the accident cost is not put on cars is removed from both cars and pedestrians and borne in a way which affects neither. The result is that in. stead of getting the theoretically better combined effect on both activities by dividing the costs, we end up getting no diminution in one and some in the other in a situation where ex hypothesis a greater diminution would save more than it would cost.

For a discussion of how placing costs on activities brings about the optimal result from a general deterrence point of view, and how this general deterrence optimum may nonc. theless differ from what we want, see Calabresi, supra note 6, 716-21.

Ironically, if it were true, as Blum and Kalven argue, that we do not know at all how to divide car-pedestrian costs between walking and driving, it would follow that even if putting part of the cost on cars and part on pedestrians did not result in externalization we could not show that the change brought about was better than that resulting from putting all the costs on driving. What Blum and Kalven must mean, therefore, is that while we cannot know precisely how to divide accident costs between cars and pedestrians so as to accomplish the best general deterrence, we can take a rough gucss, and that rough guess is the fault division. See Blum \& Kalven 63. Apart from thic problem that that rough guess may well result in a removal of part of the cost from both and, therefore, a clear error, there is very little reason for believing that "fault," with all thic moral luggage it carries, is at all equipped for making even an adequate, let alone the best, rough guess. See note 37 infra.

33. Blum \& Kalven, at 56 . See also id. at 83 . 
well and properly choose the first. In other words, we may prefer a mixed-goals system to single-minded systems.

The above conclusion follows even on the most negative of assump. tions about what we can learn from economic theory concerning the division of costs of accidents between their joint causers, and gives rise to some interesting possibilities in the way of mixed systems which it may be worthwhile to mention. A complete analysis, however, is far beyond the scope of the present discussion. Let us continue to assume for the moment that economics does not tell us how best to divide accident costs between cars and pedestrians, but does, as I have suggested, tell us that it is better that either bear all of the cost than that one bear part and the remainder be removed from both. ${ }^{34}$ If we feel that it is better from the point of view of "justice" to try to divide the cost between cars and pedestrians, then the way to do it might not be through the "vertical" fault system Blum and Kalven suggest which, because of its bad compensation effects, might result in removal of part of the cost from both. The way to divide the cost might be through those very "horizontal" plans Blum and Kalven reject.

Take for example the suggestion made by Jaffe, and in a slightly different way by Keeton and O'Connell, that as liability moves further away from fault, pain and suffering damages become anachronistic. ${ }^{33}$ If leaving pain and suffering on auto victims while putting other damages on drivers brought about a result which was acceptable from a compensation point of view, and if leaving pain and suffering on victims did not bring about an externalization or nullification of their "costs" for any of the other reasons I have suggested, then such a plan would be acceptable from a general deterrence point of view and, ex hypothesis, adequate from the standpoint of compensation. ${ }^{30}$ If in

34. See note 32 supra.

35. Jaffe, Damages for Personal Injury: The Impact of Insurance, 18 LAw \& CostessP. Prob. 219, 235 (1953); Keeton \& O'Connell, Basic Protection-A Proposal for Imfroving Automobile Claims Systems, 78 HaRv. L. REv. 329, 356-57, 371, $381-82$ (1964). The authors do not provide compensation for pain and suffering under their proposed plan. They do suggest self-insurance, and they allow supplementary recoveries (including pain and suffering damages) based on the fault principle in cases of "serious injury."

36. This assumes that the prospect of bearing the monetary cost of pain and suffering would affect the habits of potential victims. This assumption implies both that potential victims who wished to insure against pain and suffering would obtain, such insurance for pain and suffering specifically resulting from automobile accidents and not as part of an all-encompassing pain and suffering insurance policy, and that the prospect of no compensation for pain and suffering would affect their habits. If potential victims could not insure separately for pain and suffering resulting from specific activities, then placing pain and suffering costs on them would result in externalization.

If we assume, instead, that the habits of potential victims would be the same whether 
addition such a division of costs between "drivers" and "victims" had the effect of minimizing the expense of administering the system, it might turn out to be quite a good plan for meeting our goals of accident law.

But, as I have said, this is not the place to examine systems. And such a division of costs might be inadequate because it failed to meet other goals such as specific deterrence, or our sense of justice. It might also be inadequate if economics gives a more specific answer as to how to divide costs between cars and pedestrians than we have here admitted for the sake of staying close to Blum and Kalven's argument. ${ }^{37}$

or not they were made to bear some monetary cost of pain and suffering, because it is the prospect of bearing the pain and suffering itself, not the lack of compensation for it, which influences potential victims, then externalization of pain and suffering would, in a sense, be impossible. Potential victims, it would seem, would always be affected by the prospect.

While externalization would be impossible, this is no guarantee that the effect that the prospect of pain and suffering would have on the habits of potential victims would be optimal. Such optimal effect would require that potential victims correctly cvaluate the risk of pain and suffering coming about, which is most unlikely. Indeed, I would guess that, ex ante, potential victims evaluate the risk of pain and suffering coming about at a lower value than that at which they, when serving on juries, are willing to compensate others, after accidents, for similar pain and suffering. If I am right, an argument may cxist for putting at least the difference between these $e x$ post and $e x$ ante valuations on nonvictims (drivers). Cf. note 32 supra. How strong the argument is would depend not only on the validity of the basic assumption that it is the prospect of the pain and suffering itself, and not its cost, which influences the habits of potential victims, but also on the extent of the discrepancy between individuals' ex ante valuation and ex post "jury type" valuations, and on the cost of making such $e x$ post valuations. Sec Calabresi, note 6 supra, 721-24.

37. In the last paragraph of note 32, supra, I have suggested that Blum and Kalven, despite themselves, do feel that some rough guess as to the proper division of costs between cars and pedestrians is possible from a gencral deterrence point of view. And I have suggested that they feel that division is fault. Cf., BLUM \& KALvEN at 63. This is not the place to analyze how much more can be said on the question of how to divide costs in such situations. In 78 HARv. L. REv. 713, 734-42, I make some suggestions in that regard. Whether the answer lies in the "involvement" test there suggested, or in a more sophisticated division based on involvement but in proportion to other, non-accident, costs attributable to the parties involved, or in some totally different division, requires much more than a footnote.

Among possible totally different divisions is one that might be termed "ease of avoidance" or non-fault fault. Such a division would involve a rough and ready guess as to the degree to which each of the various parties involved could have avoided the accident costs most cheaply, and would contemplate a division of costs between the parties which would reflect this. This guess is, despite its sound, very different from "fault." Some of the more obvious differences are: 1) This guess can, if efficiency justifies it, be made by classes or activities ("driving" as against "walking") and is not restricted, as fault is, to a more expensive individual case-by-case basis. 2) Even if the division were made on a case-by-case basis, some party would always be found who could have avoided the cost more casily. Or, if both could have avoided the cost as easily, there would be a $50-50$ split (i.e., the situation of a total burden on the "innocent" victim because the party who injured him did 
If economics does provide a more specific answer, agnostic splitting between cars and pedestrians might not be the best we could do, although general deterrence being only one of our aims, failure to meet all the requirements of general deterrence would certainly not rule out such a plan. Still, the best that can be said for Blum and Kalven's attempt to show these "horizontal" plans to be unsatisfactory is that they fail to prove their case.

I have, however, been hard on Blum and Kalven long enough. And it is time to try to point out how truly significant and impressive their small book is-despite its wrong conclusions. In the first place, their work should make it impossible for scholars or courts blithely to say "risk spreading" and assume that they have solved the very complex question of who ought to bear what share of the cost of accidents, or, indeed, that they have said very much at all. In the second place, this book will require those scholars who tend to hide behind economics to make clear just how far their economics carries them. In the third place, by highlighting social insurance as a feasible alternative against which all accident plans must be judged, Blum and Kalven force us to consider what goals of accident law social insurance, cheap and effective as it is, fails to accomplish. In so doing, they necessarily cause us to consider which mixed plan, or mixture of plans, does in fact best accomplish our goals.

They, themselves, fail to make this investigation, ${ }^{38}$ despite their protests to the contrary, and therefore end up supporting a system

not meet the criteria of being at "fault," though that party, or the activity he engaged in. could have avoided the cost more easily than the victim, would not exist). 3) There would, ex hypothesis, be a "comparative" ease-of-avoidance test (by individuals or activitics involved) and not an all-or-nothing ease-of-avoidance test. (In effect this would be like moving to comparative negligence, and then dropping the negligence aspect.) 4) The "moral luggage" of fault would be irrelevant.

The advantage of this form of division is that it would concentrate on the question of minimizing social costs caused by all accidents and would not concentrate, as fault today does, on minimizing fault-caused accident costs. Cf. Coase op. cit. supra, note 28, at 27-28; BluM \&: KaLven 63-64 text and notes. But compare Calabresi, note 6 stpra, 732, 739, with id. at 741. Whether such a division is acceptable, even from a general deterrence point of view, depends on whether it causes externalization of part of the cost. This in turn depends in part on whether such a division is acceptable from a risk spreading point of view. Sec notes 29-33 supra and accompanying text. Whether this guess is best done by "catcgories" (driving as against walking, driving as against motorcycles) or on a case-by-case basis is a question of, on the one hand, how much better general deterrence we get by individualization and, on the other hand, how expensive this individualization is. In other words, is individualization worth its cost?

38. Except for one brief and rather superficial but interesting attempt at 83-85, where the authors mention various proposals combining the approsches of social security and fault. 
which they do not show to be at all superior to any other discussed. But this failure does not detract from their accomplishment. Hereafter any plan proposed will have to be examined in a much more thorough way than we have admitted in the past. The fact is that to varying extents we all want our laws dealing with automobile accidents (and all accidents really): a) to give compensation sufficient to minimize secondary losses and to make the loss burden politically tolerable; b) to provide specific deterrence sufficient to prevent "useless acts" reasonably well ${ }^{39} \mathrm{c}$ ) to provide a certain amount of internalization of costs, so that costs of accidents do not just become a "cost of living" and are made, instead, to affect both the degree to which we engage in activities which tend to result in accidents and the way in which we perform those activities; d) to satisfy certain "justice" and "revenge" requirements (some of which are undifferentiated and some of which are for me just plain unintelligible); and e) to do each of the above in a sufficiently efficient and and inexpensive way that we do not spend more in achieving the goal than it is worth. ${ }^{40} \mathrm{It}$ is also true that even if Blum and Kalven have shown that most compensation schemes heretofore suggested do not accomplish each of these goals perfectly, they have failed to show that the current fault scheme accomplishes any of them optimally. And they certainly fail to show that fault meets the combination of these goals better than any of the schemes they criticize. Nevertheless, as a result of their book we can begin to compare how well different plans or combinations of plans give us what we want. And perhaps within what we currently think of as the area of accident law, or perhaps, in whole or in part outside that area, we can find a somewhat more satisfactory solution than that which we have so far been given.

39. Blum \& KALVEN, at 63.64 , are quick to point out that criminal penalties and licensing controls might hold down accident waste more efficiently than liability rulcs which attempt to make activities related to motoring bear their appropriate shares of accident costs. Whatever the validity of their argument, it is amusing that it should comc from such devoted advocates of the free market system.

40. Cf., 2 HARPER \& JAMEs, TORTS 742-43 (1956). 